\title{
EFFECT OF SEASONAL TILLAGE ON SOME SOIL PROPERTIES, ENERGY PARAMETERS AND PRODUCTIVITY UNDER RECLAIMED SOIL
}

\author{
Khater, M. M. I.*
}

\begin{abstract}
This study was focusing on energy parameters for tillage conditions of New El Salhia region, where dryland conditions were occurred. Soil texture was sandy loam. The methodology used in the calculation of consumed energy was divided into inputs and outputs to identify the energy ratio. Data from field experiment were used to determine some soil physical properties, energy indices and yield of wheat and corn as affected by tillage treatments. Tillage treatments included conventional system (chiselhing twice and harrowing), Minimum tillage (chiselling) and another minimum tillage system (harrowing). The soil bulk density and moisture content was determined for two depth until $30 \mathrm{~cm}$. From the above mentioned it can be concluded that the minimum tillage using chisel plow might be necessary to conserve the moisture content and improve soil structure which consequently gave profitable yield from the energy point of view. The results showed that the conventional tillage treatments had the highest grain and biomass yield while harrowing treatments had the lowest values. The conventional tillage treatments gave the most net energy gain of (52.34 and $163.85 \mathrm{GJ})$ meanwhile the harrowing treatments gave the least ones (47.46 and $156.61 \mathrm{GJ}$ ) for wheat and corn respectively. The latter results mean that conventional tillage treatments were recommended for dryland farming of wheat and corn in El Salhia region. These results also will be helpful in developing a comprehensive database on the energy parameters of tillage implements for Egyptian agricultural machinery management.
\end{abstract}

Keywords: soil physical properties, yield, energy indices.

*Soil Conservation Department, Desert Research Center, Cairo, Egypt 


\section{INTRODUCTION}

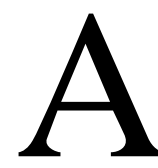

gricultural production in drylands is complex in low input farming systems characterized by drought soils, insufficient energy requirements and low yields, hence there were needs to investigate soil and energy conservation under improved farming systems as an option to the tradition farming practices. (Bersgstrom $\boldsymbol{e t}$. al, 2001) clarified that improved conservation tillage systems have become an important technology, which useful in decreasing energy requirements and increasing yields. Drought is a major problem in the arid areas as it results in huge losses in crop yields, mainly due to loss of water and energy. (Islam et. al, 2008) reported that the use of improved conservation tillage techniques can help in reducing soil evaporation as they provide mulch, which reduces the infiltration rates and increase soil water retention. (Lopez et al., 2003) compared the effects of conventional tillage and conservation tillage systems for soil water content on loam soil, the effects of no-till had from 26 less to $17 \%$ stored soil water (0-80 $\mathrm{cm}$ ) than conventional tilled plots at the beginning of the growing season. Soil bulk density is an important indicator which affect total quantity of water in the soil and evaporation from the soil. (Sanchez and Jama, 2000) added that tillage practices that reduces soils disturbance improve soil bulk density and hence soil moisture content. Conventional tillage systems involving sequence plowing were promoted to destroy soil structure and rapidly reduce productivity after a few years of continuous cultivation (Islam et. al, 2007). (Norwood 1994) found 62\% more water in the $0-90 \mathrm{~cm}$ depths in no-till. due to less evaporation compared to conventional tillage. In another study (Nyagumbo 2002), found more water under conservation tillage practices of mulch ripping, when compared to conventional tillage. Effects on maize yields have been observed on conservation tillage practices produce higher yields than conventional one Munyati (1997), (Hussein et al.,1999) found lower yields in no-till in the first year, but later yielded more than conventional tillage. In contrast (Kapustan et al., 1996) reported no differences in maize yields between no-till and conventional tillage over time. Chisel plow is one of the most common and important primary tillage implements in Egyptian farming that can effectively cut and pulverize the 
soil up to a depth of $20 \mathrm{~cm}$ (Islam 2010), (Schillinger and Papendick 1997) in a study under arid conditions of eastern Washington observed that deep tillage increased grain yield from 4.4 to $5.3 \mathrm{Mg} / \mathrm{ha}$ compared with shallow tillage. (Gicheru et al.,2004) working in eastern Kenya reported that there was an increase in amount of soil water stored with conservation tillage and the response of crops to the improved water availability was very clear. Energy parameters can be used to assess the efficiency of production systems and to make comparisons among systems (Haciseferogullari et al., 2003). All inputs and outputs of a cropping system can be expressed in terms of energy. Differences in management practices such as tillage and crop rotation have considerable effects on energy input and energy efficiency of crop production systems. Management practices (tillage, pesticides, fertilizer, crop, rotation) used within a crop production system affect the energy balance of that system. The use of conservation tillage was associated with lower energy inputs relative to conventional tillage systems. Cropping systems that use commercial fertilizer, especially $\mathrm{N}$, use greater amounts of energy than systems that use no commercial fertilizer (Rathke and Diepenbrock, 2006). (Swanton et al. 1996) concluded that energy use has decreased as crop yields have increased due to improved crop resulting in increased energy efficiency in crop production. Hence, energy efficiency can be increased by decreasing energy use from inputs such as fertilizer or tillage operations or by increasing outputs such as crop yield. Energy balance information for crops would be useful for improving the efficiency of production systems. In arable crops cultivation, tillage is one of the greatest energy consumers. Therefore, the selection of an appropriate tillage method includes assessments of the system's energy conservation. (Borin et al. 1997) reported that $30 \%$ of energy in the field is consumed by tillage. Reducing tillage intensity reduces fuel consumption, increases the energy ratio, and decreases time and energy required for seedbed preparation.

Therefore, the present research aimed to:

1. evaluate and compare the changes in some soil properties of sequenced seasonally tillage operations during the cropping phase of a wheat and corn, under minimum and traditional tillage systems. 
2. assess and compare the energy indices yield parameters for different tillage systems used in the region studied

3. find out the best of tillage systems on yields subjected to cropping phases.

\section{MATERIALS AND METHODS}

A private farm in New El Salhia was selected to carry out the field experiments (Long 32 $05^{\prime} 29^{\prime \prime}$ - Lat $30^{\circ} 48^{\prime} 18^{\prime \prime}$ ). The soil of the experimental plots was textured as sandy loam $(63.49 \%$ sand, $29.07 \%$ silt and $7.44 \%$ clay). Particle size distribution of soil was determined according to (Klute 1986). Giza 25 corn variety was used as an indicator plant, at a rate planting of $36 \mathrm{~kg} / \mathrm{ha}$ and Giza 93 wheat variety was used as an indicator plant, at a rate of planting of $143 \mathrm{~kg} / \mathrm{ha}$. The irrigation was applied using sprinkler irrigation. Both field crops were successive through 2014 and 2015.

Three different tillage practices were examined to identify their effect on soil bulk density, soil moisture content and energy parameters as well as yields of wheat and corn.

\section{Field operations:}

Two wheel drive Belarus MTZ Tractor, with $90 \mathrm{hp}(66.24 \mathrm{~kW})$ and Diesel fuel type was used for tillage operations.

The experimental unit area was $60 \mathrm{~m}^{2}(12 \times 5 \mathrm{~m})$. The experiments consisted of 2 minimum tillage practices comparing with a treatment of conventional tillage system (control treatment) for both two experimental field crops as illustrated in table (1):

A- Conventional tillage system (control treatment) using chiseling twice+ disc harrowing + planting.

B- Minimum tillage using chiseling once + planting.

$\mathrm{C}$-Minimum tillage using harrowing once + planting.

Field experiments were conducted and treatments were arranged in a split- split plot design with three replicates. All field operations were done on forward speed of $3.2 \mathrm{~km} / \mathrm{h}$.

Table (1): Applied treatments of the field experiments. 


\begin{tabular}{|c|c|c|}
\hline Treatments & $\begin{array}{c}\text { 1st season } \\
\text { (Wheat) }\end{array}$ & $\begin{array}{l}\text { 2nd season } \\
\text { (Corn) }\end{array}$ \\
\hline $\begin{array}{l}\text { Conventional tillage } \\
\text { (control treatment) }\end{array}$ & $\begin{array}{l}\text { chiseling twice } \\
\text { + disc harrowing } \\
\text { + planting. }\end{array}$ & $\begin{array}{l}\text { chiseling twice } \\
\text { + disc harrowing } \\
\text { + planting. }\end{array}$ \\
\hline Minimum tillage & $\begin{array}{l}\text { chiseling once } \\
+ \text { planting }\end{array}$ & $\begin{array}{l}\text { chiseling once } \\
+ \text { planting }\end{array}$ \\
\hline Minimum tillage & $\begin{array}{l}\text { harrowing once } \\
\quad+\text { planting }\end{array}$ & $\begin{array}{l}\text { harrowing once } \\
+ \text { planting }\end{array}$ \\
\hline
\end{tabular}

Field measurements:

Soil bulk density and soil moisture content were measured on each plot after each tillage operation and before harvesting. All measurements related to these properties were performed with regard to row position.

\section{The soil bulk density $\left(\mathrm{Mg} / \mathrm{cm}^{3}\right)$.}

Soil bulk density, $\mathrm{Mg} / \mathrm{cm}^{3}$, at soil depths of $(0-15 \mathrm{~cm})$ and $(15-30 \mathrm{~cm})$ were determined at 3 days after the planting date $\left(\mathbf{1}^{\mathbf{s t}}\right)$ and before harvesting ( $2^{\text {nd }}$ ) for each treatment using core method, (Klute 1986)

\section{The total soil porosity (\%).}

Soil porosity,\%, at soil depths of $(0-15 \mathrm{~cm})$ and $(15-30 \mathrm{~cm})$ were determined at 3 days after the planting date $\left(\mathbf{1}^{\mathbf{s}}\right)$ and before harvesting $\left(2^{\text {nd }}\right)$ for each treatment using calculation method, (Klute 1986) from real bulk density (pr) and bulk density (pd) as the following equation.

\section{Total soil porosity $=(\mathbf{p r}-\mathbf{p d}) / \mathrm{pr}$}

\section{The gravimetric soil moisture content, $(\%)$}

The soil moisture content, $\%$ of the projected area was measured at soil depths of $(0-15 \mathrm{~cm})$ and $(15-30 \mathrm{~cm})$, then determined after 3 days of planting as a $\left(\mathbf{1}^{\text {st }}\right)$ record and before harvesting as $\left(2^{\text {nd }}\right)$ record, using the oven dry method. (Klute 1986).

\section{Yield (Mg/ha).}

The wheat and corn were harvested at the end of the cropping seasons after the crops have reached to physiological maturity. The air dried material was then separated to determine the grain and chaff yields. The biomass yield (grain and chaff) was weighed accordingly. Least 
significant difference (LSD) test was used for the comparison among treatments means, (Steel and Torrie 1980).

\section{Energy Indices}

The parameters measured or calculated were input energy, output energy, net energy gain, energy ratio (energy efficiency), and energy productivity.

\section{Energy inputs, (Ei)}

Energy inputs can be classified in two main groups: direct-use energy and indirect-use energy. Direct and indirect energy inputs were calculated as seen in Eq. (1) for biological energy (BE: human labor, seed) and field operational energy (FOE). Energy equivalents (EE) for all inputs were summed to provide an estimate for total energy input.

$\mathbf{E} \mathbf{i}=\mathbf{B E}+\mathbf{F O E}$

\section{Biological energy (BE)}

The energy analysis of farming systems implies an assessment of the energetic of human labor (Mario and Pimentel 1991). The BE for tractor operator as well as for farm labor was calculated as below

$\mathrm{BE}=$ Labor $\mathrm{x}$ hours of work/ha $\mathrm{x} \mathrm{EE}$

For this purpose, the work days for agricultural workers and farm machinery operators were estimated to be 207 days per year with an average of $8 \mathrm{~h}$ work per day.

EE for human labor and tractor operator was 1.95 and $1.05 \mathrm{MJ} \mathrm{h}^{-1}$

Field operation energy (FOE)

FOE was specified for each machine in a field operation, fuel was measured by the fuel tank and mass method. Fuel energy (EF) was determined as:

$\mathbf{E F}=\mathbf{Q i} \times \mathbf{E E}$

where EE is the energy equivalent; EF the fuel energy (MJ. $\mathrm{L}^{-1}$ ), and Qi the fuel consumption $\left(\mathrm{L} . ~^{-1}\right)$. The energy equivalent for Diesel fuel is $50.23 \mathrm{MJ} \mathrm{L}^{-1}$.

Energy related to tractor or machine operations was determined by

$\mathrm{MaE}=(\mathrm{m} \times \mathrm{ee}) \times \mathrm{Fe} / \mathrm{u}$ 
where $\mathrm{MaE}$ is the energy for machine or tractor $\left(\mathrm{MJ} . \mathrm{h}^{-1}\right) \mathrm{m}$ the mass $(\mathrm{kg})$; ee the yearly energy for equipment: for the tractor $9.5 \mathrm{MJ}$. (kg. year ${ }^{-1}$ and for the machines $7 \mathrm{MJ}(\mathrm{kg} \text {. year })^{-1}$, u the work hours per year ;and Fe the operational work capacity $\left(\mathrm{h} \mathrm{ha}^{-1}\right)$. Energy for FOE was considered to be fuel energy plus energy of machinery operations.

\section{Energy output, (Eo)}

The biomass yield is the grain and chaff. According to (Pimentel and Pimentel 1996) energy output from the product (grain) was calculated by multiplying the amount of production and its corresponding energy equivalent of 12.2 and $15.6 \mathrm{MJ} \mathrm{kg}^{-1}$ for wheat and corn respectively. Energy output from the by-product (chaff) was estimated by multiplying the amount of by-product and its corresponding equivalent $\left(9.25 \mathrm{MJ} \mathrm{kg}^{-1}\right)$ for both wheat and corn.

\section{Net energy gain (NEG)}

NEG, or net energy production, is the difference between the gross energy output produced and the total energy required to obtain it (energy input). In agricultural processes, this energy is normally related to the unit of production.

\section{Energy ratio (ER)}

ER is defined as the ratio between the caloric heat of the output products and the total sequestered energy in the production factors. This index reveals the influence of the inputs expressed in energy units in obtaining consumer goods normally related to food production, but which can be applied appropriately to the energy balance of biomass production. This index was determined as energy output divided by input.

$\mathbf{E R}=\mathbf{E o} / \mathbf{E i}$

\section{RESULTS AND DISCUSSION}

Soil bulk density as affected by the experimental treatments.

Concerning the bulk density, results in Table (2) showed that soil bulk density values after 3 days of the planting date were lower than that obtained before harvesting under the same studied depth for all treatments. On the other hand, the chiseling and harrowing treatments at first and second records, were obviously higher than the conventional tillage treatment. These higher values could be attributed to less 
disturbing soil and increasing of soil stability, consequently increased soil bulk density. The soil bulk density values for both two records under studied treatments ranged from 1.41 to 1.61 and 1.43 to $1.64 \mathrm{Mg} / \mathrm{cm}^{3}$, for wheat and corn respectively. Generally the comparative effect of plowing indicated that the harrowing treatments had the highest soil bulk density values, while other values were ranked as chiseling treatments > conventional treatments. The values of soil bulk density revealed that summer season of corn had the highest soil bulk density values as compared with the winter season of wheat. These higher values could be due to the reorientation of soil particles and increased soil compaction resulted from the wetting and drying cycles during growing season, consequently increased soil bulk density in the second growing season. Such results were in agreement with the finding of (Raper et al., 2005).

Total soil porosity as affected by the experimental treatments.

Upon total soil porosity data in table (2) reveal an opposite trend to that obtained for bulk density as the lower the soil bulk density, the greater total soil porosity to be.

Table (2): Effect of tillage practices on soil bulk density and total porosity

\begin{tabular}{|c|c|c|c|c|c|c|c|c|}
\hline \multirow{4}{*}{ Treatments } & \multicolumn{8}{|c|}{ Soil bulk density $\left(\mathrm{Mg} / \mathrm{cm}^{3}\right)$} \\
\hline & \multicolumn{4}{|c|}{$1^{\text {st }}$ Season (Wheat) } & \multicolumn{4}{|c|}{$2^{\text {nd }}$ Season (Corn) } \\
\hline & \multicolumn{2}{|c|}{$\begin{array}{l}\text { 0- } 15 \mathrm{~cm} \\
\text { depth }\end{array}$} & \multicolumn{2}{|c|}{$\begin{array}{c}\text { 15- } 30 \mathrm{~cm} \\
\text { depth }\end{array}$} & \multicolumn{2}{|c|}{$\begin{array}{l}\text { 0- } 15 \mathrm{~cm} \\
\text { depth }\end{array}$} & \multicolumn{2}{|c|}{$\begin{array}{c}\text { 15- } 30 \mathrm{~cm} \\
\text { depth }\end{array}$} \\
\hline & $1^{\text {st }}$ & $2^{\text {nd }}$ & $1^{\text {st }}$ & $2^{\text {nd }}$ & $1^{\text {st }}$ & $2^{\text {nd }}$ & $1^{\text {st }}$ & $2^{\text {nd }}$ \\
\hline $\begin{array}{c}\text { Conventional } \\
\text { tillage }\end{array}$ & 1.41 & 1.43 & 1.44 & 1.48 & 1.42 & 1.44 & 1.47 & 1.49 \\
\hline Chiseling & 1.52 & 1.54 & 1.59 & 1.60 & 1.50 & 1.53 & 1.56 & 1.60 \\
\hline \multirow[t]{5}{*}{ Harrowing } & 1.54 & 1.55 & 1.61 & 1.61 & 1.53 & 1.54 & 1.54 & 1.64 \\
\hline & \multicolumn{8}{|c|}{ Total soil porosity (\%) } \\
\hline & \multicolumn{4}{|c|}{$1^{\text {st }}$ Season (Wheat) } & \multicolumn{4}{|c|}{$2^{\text {nd }}$ Season (Corn) } \\
\hline & \multicolumn{2}{|c|}{$\begin{array}{l}0-15 \mathrm{~cm} \\
\text { depth }\end{array}$} & \multicolumn{2}{|c|}{$\begin{array}{l}\text { 15- } 30 \mathrm{~cm} \\
\text { depth }\end{array}$} & \multicolumn{2}{|c|}{$\begin{array}{l}0-15 \mathrm{~cm} \\
\text { depth }\end{array}$} & \multicolumn{2}{|c|}{$\begin{array}{c}15-30 \mathrm{~cm} \\
\text { depth }\end{array}$} \\
\hline & $1^{\text {st }}$ & $2^{\text {nd }}$ & $1^{\text {st }}$ & $2^{\text {nd }}$ & $1^{\text {st }}$ & $2^{\text {nd }}$ & $1^{\text {st }}$ & $2^{\text {nd }}$ \\
\hline $\begin{array}{c}\text { Conventional } \\
\text { tillage }\end{array}$ & 46.79 & 46.03 & 45.66 & 44.15 & 46.41 & 45.66 & 44.52 & 43.77 \\
\hline Chiseling & 42.64 & 41.88 & 40.00 & 39.62 & 43.39 & 42.26 & 41.13 & 39.62 \\
\hline Harrowing & 41.88 & 41.50 & 39.24 & 39.24 & 42.26 & 41.88 & 41.88 & 38.11 \\
\hline
\end{tabular}

$\mathbf{1}^{\text {st: }}$ : The soil parameter determined after 3 days of planting.

$\mathbf{2}^{\mathbf{n d}}$ : The soil parameter determined before harvesting. 


\section{Soil moisture content as affected by the experimental treatments.}

Soil moisture content was determined throughout the two cropping seasons after 3 days of planting and before harvesting at two mentioned depths of 0-15, 15-30. Data in Table (3) showed the comparative effect of tillage practices on soil moisture content values. The result elucidated that the harrowing treatments had the highest soil moisture content values during both growing seasons of two recorded time values and different studied depths. The soil moisture content values were ranked as: harrowing treatments $>$ chiseling treatments $>$ conventional treatments. This trend might be attributed to that the harrowing keep the soil without much disturbance, thus more soil ability for water retention which increased with depth and this agrees with (Lindwall $\boldsymbol{e t}$ al, 1984)

Table (3): Effect of tillage practices on soil moisture content

\begin{tabular}{|c|c|c|c|c|c|c|c|c|}
\hline \multirow{4}{*}{ Treatments } & \multicolumn{8}{|c|}{ Soil moisture content (\%) } \\
\hline & \multicolumn{4}{|c|}{$1^{\text {st }}$ Season (Wheat) } & \multicolumn{4}{|c|}{$2^{\text {nd }}$ Season (Corn) } \\
\hline & \multicolumn{2}{|c|}{$\begin{array}{l}0-15 \mathrm{~cm} \\
\text { depth }\end{array}$} & \multicolumn{2}{|c|}{$\begin{array}{c}\text { 15- } 30 \mathrm{~cm} \\
\text { depth }\end{array}$} & \multicolumn{2}{|c|}{$\begin{array}{c}0-15 \mathrm{~cm} \\
\text { depth }\end{array}$} & \multicolumn{2}{|c|}{$\begin{array}{c}\text { 15- } 30 \mathrm{~cm} \\
\text { depth }\end{array}$} \\
\hline & $1^{\text {st }}$ & $2^{\text {nd }}$ & $1^{\text {st }}$ & $2^{\text {nd }}$ & $1^{\text {st }}$ & $2^{\text {nd }}$ & $1^{\text {st }}$ & $2^{\text {nd }}$ \\
\hline $\begin{array}{c}\text { Conventional } \\
\text { tillage }\end{array}$ & 11.35 & 14.16 & 17.35 & 20.11 & 8.89 & 9.78 & 12.13 & 19.16 \\
\hline Chiseling & 13.54 & 16.85 & 19.66 & 24.23 & 9.64 & 11.97 & 14.76 & 19.28 \\
\hline Harrowing & 13.59 & 16.87 & 20.44 & 28.53 & 9.94 & 12.33 & 15.19 & 19.65 \\
\hline
\end{tabular}

$\mathbf{1}^{\text {st: }}$ : The soil moisture content after planting.

$2^{\text {nd }}$ : The soil moisture content before harvesting.

From the soil depth point of view, the soil moisture content values revealed that the soil keeps more water in (15-30) $\mathrm{cm}$ depths as compared with the $(0-15) \mathrm{cm}$. Also, the obtained results indicated that soil moisture content values before harvesting were higher than that obtained at the first irrigation after planting under studied treatments. This higher value of soil moisture content could be due to the reorientation of soil particles resulting from the wetting and drying cycles during growing season. This trend was obvious in winter season of wheat as compared with the summer season of corn. 


\section{Effect of tillage practices on energy parameters:}

Data in Table (4) showed that the conventional treatments had the highest energy indices values and harrowing treatments had the lowest one for both wheat and corn. The treatments could be ranked as conventional tillage > chiseling > harrowing from energy indices point of view. This finding is consistent with the (Borin $\boldsymbol{e t}$ al. 1997). who reported that the average input energy per hectare is proportional to the tillage intensity in such a way that, the greater the decrease in soil manipulation intensity, the greater the energy ratio. It was recommended that chisel plow was the most energy efficient implement in terms of fuel consumption and specific energy.

Using the conventional treatments led to increase energy consumption as compared with other treatments. This could be attributed to more fuel consumption exerted higher required energy values These results were in agreement with the finding of (Mari and Changyine 2007).

\section{The effect of tillage practices on biomass yield.}

As seen from this Table (5), generally conventional tillage treatments had higher yields relative to minimum tillage treatments of both chiseling and harrowing during the two seasons. The conventional treatments had the highest yields, with a grain yield mean of (1874 and $\left.8283 \mathrm{~kg} \mathrm{ha}^{-1}\right)$ for wheat and corn respectively, and biomass yield mean of (6537 and 18619 $\mathrm{kg} \mathrm{ha}^{-1}$ ) for wheat and corn respectively. The harrowing treatments had the lowest yields, with a grain yield mean of (1733 and $\left.7611 \mathrm{~kg} \mathrm{ha}^{-1}\right)$ for wheat and corn respectively, and biomass yield mean of (5417 and 17227 $\mathrm{kg} \mathrm{ha}^{-1}$ ) for wheat and corn respectively. The benefits of improved soil physical properties accrued during the growing seasons were effectively translate to improved yields. Maintaining the upper layer of the soil for the purpose of facilitating root growth, consequently vegetation growth and crop yield were relatively high while both minimum tillage treatments does not disturb enough the soil through plowing. (Chikowo et al., 2003). 
Table (4): Effect of tillage practices on energy indices.

\begin{tabular}{|c|c|c|c|c|c|c|c|c|}
\hline \multirow{3}{*}{ Treatments } & \multicolumn{8}{|c|}{ Energy(MJ/ha) parameters for wheat } \\
\hline & \multicolumn{4}{|c|}{ Inputs } & \multirow[b]{2}{*}{$\begin{array}{l}\text { Total } \\
\text { Inputs }\end{array}$} & \multirow[b]{2}{*}{ Outputs } & \multirow{2}{*}{$\begin{array}{c}\text { Net } \\
\text { energy } \\
\text { gain } \\
\text { (MJ) }\end{array}$} & \multirow[b]{2}{*}{$\begin{array}{c}\text { Energy } \\
\text { ratio }\end{array}$} \\
\hline & $\begin{array}{l}\text { Labor } \\
\text { (BE) }\end{array}$ & $\begin{array}{c}\text { Fuel } \\
\text { consump. } \\
\text { L/ha }\end{array}$ & FE & MaE & & & & \\
\hline $\begin{array}{c}\text { Conventional } \\
\text { tillage }\end{array}$ & 3 & 63.78 & 3203.87 & 4920 & 8123.87 & 60467.25 & 52340 & 7.44 \\
\hline Chiselling & 3 & 24.27 & 1219.38 & 1520 & 2739.38 & 53918.25 & 51180 & 19.74 \\
\hline \multirow[t]{2}{*}{ Harrowing } & 3 & 15.23 & 765.1 & 1880 & 2645.1 & 50107.25 & 47460 & 18.97 \\
\hline & \multicolumn{8}{|c|}{ Energy(MJ/ha) parameters for corn } \\
\hline $\begin{array}{c}\text { Conventional } \\
\text { tillage }\end{array}$ & 3 & 68.82 & 3457.31 & 4920 & 8377.31 & 77490.12 & 163850 & 20.57 \\
\hline Chiselling & 3 & 25.94 & 1303.06 & 1520 & 2823.06 & 26113.36 & 162350 & 58.57 \\
\hline Harrowing & 3 & 16.94 & 851.17 & 1880 & 2731.17 & 25263.39 & 156610 & 58.36 \\
\hline
\end{tabular}

Table (5): The effect of tillage practices on dried yield ( $\mathrm{kg} / \mathrm{ha})$.

\begin{tabular}{ccccc}
\hline & \multicolumn{2}{c}{ Wheat } & \multicolumn{2}{c}{ Corn } \\
\cline { 2 - 5 } Treatment & $\begin{array}{c}\text { Grain } \\
\text { yield }\end{array}$ & $\begin{array}{c}\text { Biomass } \\
\text { yield }\end{array}$ & $\begin{array}{c}\text { Grain } \\
\text { yield }\end{array}$ & $\begin{array}{c}\text { Biomass } \\
\text { yield }\end{array}$ \\
\hline $\begin{array}{c}\text { Conventional } \\
\text { tillage }\end{array}$ & 1874 & 6537 & 8283 & 18619 \\
Chiselling & 1768 & 5829 & 7820 & 17857 \\
Harrowing & 1733 & 5417 & 7611 & 17227 \\
LSD 0.05 & 109 & 782 & 718 & 1902 \\
\hline
\end{tabular}




\section{CONCLUSION}

This study focusing on demonstration of energy parameters for tillage conditions of New El Salhia district area, where dryland conditions were occurred. Tillage practices have influences on some soil physical properties, energy and crop productivity. The methodology used in the calculation of energy use was divided into inputs and outputs to identify the energy ratio.

From the above mentioned it can be concluded that.

1) It was suggested that minimum tillage using chisel plow might be necessary to conserve the moisture content and improve the soil profile which consequently gave profitable yield from the energy point of view.

2) The results showed that the conventional tillage treatments had the highest grain and biomass yield while harrowing treatments had the lowest values.

3) It was also revealed that conventional tillage treatments showed the most net energy gain of (52.34 and $163.85 \mathrm{GJ})$ and the harrowing treatments were the least $(47.46$ and $156.61 \mathrm{GJ})$ for wheat and corn respectively.

4) With regard to the latter results and the fact that conventional tillage treatments were recommended for dryland farming of wheat and corn in El Salhia region. These results will be helpful in developing a comprehensive database on the energy balances of tillage implements for Egyptian agricultural machinery management.

\section{REFERENCES}

Bersgstrom D.W., Monreal C.M. and St Jacques E. (2001). Influences of tillage practices on $\mathrm{C}$ sequestration is scale dependent. Candian Journal of Soil science, Vol 81, pp 53-62.

Borin M., Merini C. and Sartori L. (1997). Effects of tillage systems on energy and carbon balance in north-eastern Italy. Soil and Tillage Res. 40(3):209-26. 
Chikowo R., Mapfumo P., Nyamugafata P., Nyamadzawo G. and Giller K.E. (2003). Nitrate-N dynamics following improved fallows and maize root development in a Zimbabwean sand clay loam. Agroforestry Systems, 59:187-195.

Gicheru P. C. Gacene J. Mbuvi and Mare E.(2004). Effects of soil management practices and tillage systems on surface soil water conservation and crust formation on a sandy loam in semi-arid Kenya. Soil and tillage Res. 75(2):173-184.

Haciseferogullari H., Acaroglu M. and Gezer, I., (2003). Determination of the energy balance of the sugar beet plant. Energy Sources 25 (1), 15-22.

Hussein I., Olson K.R. and Elbar S.A. (1999). Impacts of tillage and no tillage on production of maize and soyabean on an eroded Illinosol silt loam soil. Soil and Tillage Research, 52: 37-49.

Islam M. M. Khater, Mona M. A. Hassan' Mladen Todorovic and Mohamed F. Kassab (2007). Assessment of conservation tillage techniques in sugar beet production. pp 343-353. Status of Mediterranean Soil Resources: Actions needed to support their sustainable use. Tunis, Tunisia 26 - 31 May 2007.

Islam M.M. Khater, Mona M. A. Hassan and Baran Yaser (2008). Energy Consumed for Barley Production in the Reclaimed Lands of Egypt. J. Agri. Mach. Sci. 4 (2), 171 - 178.

Islam M. M. Khater (2010). Effect of some chisel plow patterns on soil physical properties and productivity in El- Tina plain. Egypt. J. of Appl. Sci., 26(7)272-280.

Kapustan G., Krausz R.F. and Matthews J.L. (1996). Corn yield is equal in conventional, reduced and no till after 20 years. Agron Journal, 88: 812-817.

Klute, A. (ed.) (1986). Methods of Soil Analysis. Part 1. Physical and Minerological Properties. Am. Soc. Agron. Inc., Agronomy Series 9. USA. 1173 pp. 
Lawrence P.A., Radford B.G., Thomas G.A., Sinclair D.P. and Kay A.J. (1994). Effects of tillage practices on wheat performance in a semi-arid environment. Soil and Tillage Research, 28:347- 364.

Lopez M. V. Moret D. Garcia R. and Arrue L. (2003). Tillage effects on barley residue cover during fallow in semi-arid Aragon. Soil and Tillage Res. 72:53-64.

Lindwall C. Sawatzky B. and Timothy J. (1984). Zero tillage in Southern Alberta, Pp: 128-136. In Proceedings of Alta Soil Science Workshop, Faculty of Extension, University of Alberta. USA.

Mario G and Pimentel D (1991). Energy efficiency: assessing the interaction between humans and their environment. Ecol. Econ. 4(2):117-44.

Mari GR and Changyine J. (2007). Energy analysis of various tillage and fertilizer treatments on corn production. Am-Euras J. Agric. Environ. Sci. 2(5): 486-97.

Munyati M. (1997). Conservation tillage for sustainable crop production: Results and experiences from on-station and on-farm research in Natural region. Zimbabwe Science News, 31: 27-33.

Norwood C. (1994). Profile water distribution and grain yield as affected by cropping systems and tillage. Agron Journal, 86: 558-563.

Nyagumbo I. (2002). Effects of three tillage systems on seasonal water budget and drainage of two Zimbabwean Soils under maize. PhD Thesis, Department of Soil science and agricultural Engineering, University of Zimbabwe.

Pimentel D. and Pimentel M. (1996). Energy use in grain and legume production. In: Pimentel D and Pimentel M, editors. Food energy and society. revised ed. University Press of Colorado. p. 107-30.

Raper, R. L., Reeves D. W., Shaw J. N., Van Santen E., and Mask P. L. (2005). Using site-specific subsoiling to minimize draft and optimize corn yields. Trans. ASAE, 48(6), 2047-2052. 
Rathke G. and Diepenbrock W. (2006). Energy balance of winter oilseed rape (Brassica napus L.) cropping as related to nitrogen supply and previous crop. Eur. J. Agron. 24, 35-44.

Sanchez P.A. and Jama B.A. (2000). Soil fertility replenishment takes off in East Southern Africa. In International smp on balanced nutrition management systems for moist savanna and humid forests zone of Africa, Catonon, Benin , 9 October 2000.

Schillinger W. F. and Papendick R. I. (1997). Tillage mulch depth effects during fallow on wheat production and wind erosion control factors. Soil Sci. Soc. Am. J. 61:871-876.

Steel, R. G. D., and Torrie J. H. (1980). Principles and Procedures of Statistics. McGraw-Hill, New York.

Swanton C., Murphy S., Hume D. and Clements D. (1996). Recent improvements in the energy efficiency of agriculture: case studies from Ontario, Canada. Agric. Syst. 52 (4.), 399-418.

\section{الملخص العربى}

اثر الحراثة الموسمية على بعض خواص التربة وعناصر الطاقة والانتاجية تحت ظروف الاراضى المستصلحة التربة عناصة

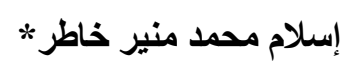

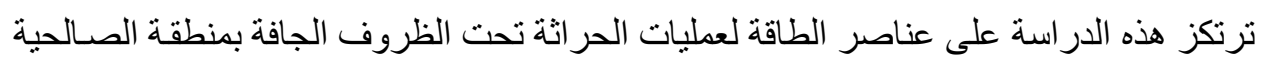

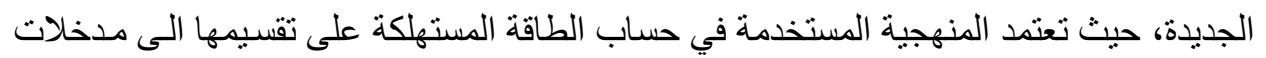

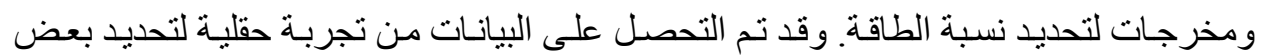

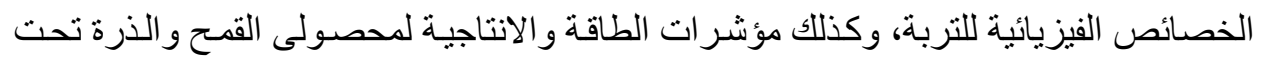

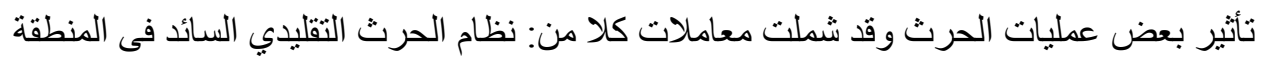

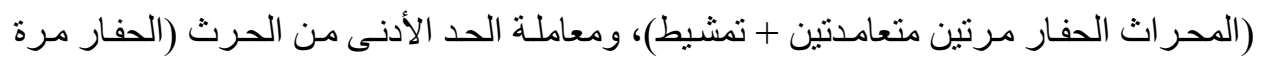

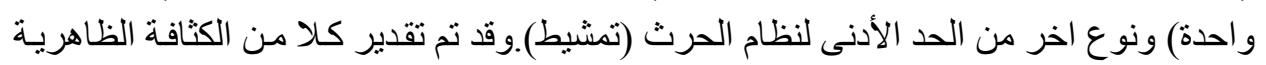

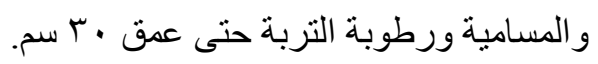

*قسم صيانة الاراضى- مركز بحوث الصحراء- القاهرة- مصر 


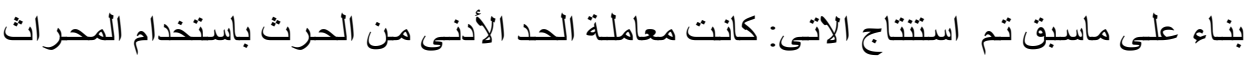

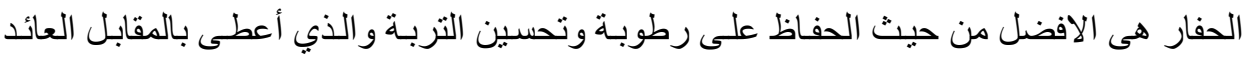

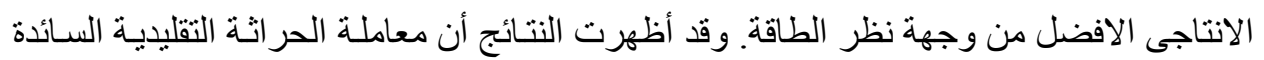

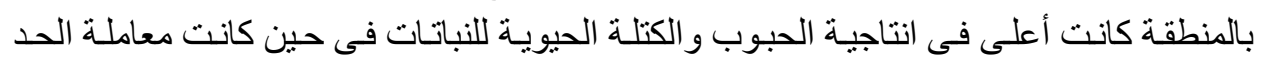

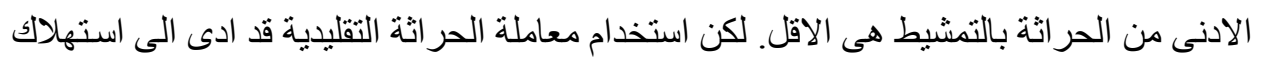

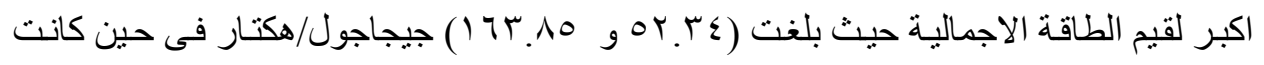

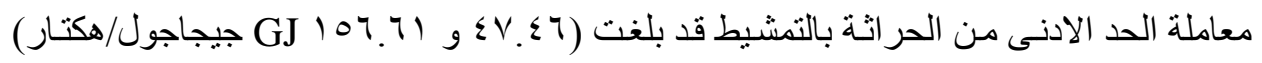

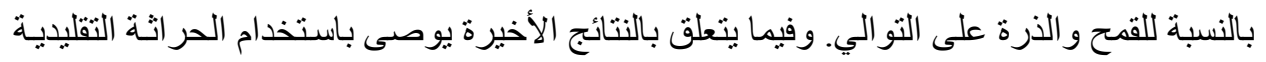

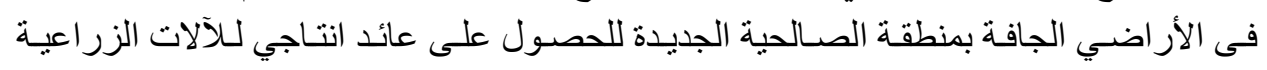
بغرض توفير استهلاك الطاقة مستقبلا بالمناطق حديثة الاستصلاح. 